DOI: $10.4274 /$ tjps. 96658

\title{
A Comprehensive Study on Thiadiazole-Based Anticancer Agents Inducing Cell Cycle Arrest and Apoptosis/Necrosis through Suppression of Akt Activity in Lung Adenocarcinoma and Glioma Cells
}

\begin{abstract}
Akciğer Adenokarsinom ve Glioma Hücrelerinde Akt Aktivitesinin Bastırılması yoluyla Hücre Döngüsü Arrestini ve Apoptozu İndükleyen Tiyadiazol Türevi Antikanser Ajanlar üzerine Kapsamlı Bir Çalışma
\end{abstract}

Gülşen Akalın Çiftçi1, Belgin Sever2, Mehlika Dilek Altıntop2 1Department of Biochemistry, Faculty of Pharmacy, Anadolu University, 26470 Eskişehir, Turkey

2Department of Pharmaceutical Chemistry, Faculty of Pharmacy, Anadolu University, 26470 Eskişehir, Turkey

\begin{abstract}
INTRODUCTION: Akt is considered as an attractive target for anticancer drug discovery and development and therefore extensive efforts have been devoted to the discovery of new potent anticancer agents targeting Akt.

METHODS: Due to the importance of thiadiazoles for anticancer drug discovery, herein eight 1,3,4-thiadiazole derivatives were investigated for their cytotoxic effects on C6 rat glioma and A549 human lung adenocarcinoma cell lines using MTT assay. The effects of the most promising anticancer agents on apoptosis, caspase- 3 activation, mitochondrial membrane potential, cell cycle arrest were determined on a BD FACS Aria (I) flow cytometer. Akt activity was measured in C6 and A549 cell lines using an ELISA colorimetric method. Schrodinger's Maestro molecular modeling package was used to explore the possible binding modes of compounds 3 and 8 in the active site of Akt enzyme (PDB code: 30W4).

RESULTS: N-(4-Chlorophenyl)-2-[(5-((4-nitrophenyl)amino)-1,3,4-thiadiazol-2yl)thio]acetamide (3) and N-(6-nitrobenzothiazol-2-yl)-2-[(5-((4-nitrophenyl)amino)1,3,4-thiadiazol-2-yl)thio]acetamide (8) induced apoptosis and cell cycle arrest in C6
\end{abstract}


cell line through the inhibition of Akt activity ( $92.36 \%$ and $86.52 \%$, respectively). The docking results of compounds 3 and 8 indicated that $\pi-\pi$ interactions, $\mathrm{H}$ bonds and salt bridge formations were responsible for the observed Akt inhibitory activity.

DISCUSSION AND CONCLUSION: According to in vitro and docking studies, compounds 3 and 8 stand out as promising antiglioma agents.

Keywords: Apoptosis, Akt activity, Cancer, Molecular docking, Thiadiazole

\section{INTRODUCTION}

Targeted cancer therapies, which are used to inhibit tumor growth, progression, and metastasis by interfering with specific molecular targets, have emerged as a promising therapeutic approach for the management of cancer. ${ }^{1}$

Akt, also known as protein kinase $B(P K B)$, is overexpressed or activated in a variety of human cancers, including gliomas, lung, breast, ovarian, gastric and pancreatic cancers. ${ }^{1,2}$ Inhibition of Akt signaling results in induction of apoptosis and inhibition of tumor growth and therefore Akt has attracted a great deal of attention as a promising target for anticancer drug discovery and development. ${ }^{1-6}$

Thiadiazole has been studied extensively for more than one hundred years due to its outstanding therapeutic applications. The sulfur atom of thiadiazole ring imparts improved liposolubility and the mesoionic nature of thiadiazoles also allows these compounds to cross cellular membranes and interact with biological targets with distinct affinities. 1,3,4-Thiadiazoles display a wide spectrum of biological activities including anticancer, antimicrobial, antiviral, antiepileptic, antidiabetic, analgesic, and anti-inflammatory activities. ${ }^{7-14}$ In particular, recent studies have pointed out the significance of 1,3,4-thiadiazole scaffold in the field of current cancer research. Thiadiazole-based anticancer agents exert potent antitumor activity against a variety of human cancer cell lines through the inhibition of diverse molecular targets including histone deacetylase (HDAC), Abl tyrosine kinase, focal adhesion kinase (FAK), Akt and tubulin polymerization. ${ }^{7-22}$

Prompted by the afore-mentioned findings, herein we focused on in vitro antiproliferative effects of a series of 1,3,4-thiadiazole derivatives on A549 human lung adenocarcinoma and $\mathrm{C} 6$ rat glioma cell lines. Further in vitro and in silico studies 
were also carried out to determine the mechanism of antitumor action of the most potent anticancer agents in this series.

\section{MATERIALS AND METHODS}

\section{Chemistry}

5-(4-Nitrophenyl)amino-1,3,4-thiadiazole-2(3H)-thione was synthesized via the ring closure reaction of 4-(4-nitrophenyl)thiosemicarbazide with carbon disulfide in the presence of potassium hydroxide. Finally, the reaction of 5-(4-nitrophenyl)amino1,3,4-thiadiazole-2(3H)-thione with $\quad N$-(alkyl/aryl)-2-chloroacetamide/4(chloroacetyl)morpholine in the presence of potassium carbonate afforded compounds 1-8. The synthetic procedure and the spectral data of compounds 1-8 were reported previously by our research group. ${ }^{23}$ The chemical structures of the test compounds were given in Table 1.

\section{Biochemistry}

Cell culture and drug treatment

C6 Rat glioma and NIH/3T3 mouse embryonic fibroblast cells were incubated in Dulbecco's Modified Eagle's Medium (DMEM) (Sigma, Deisenhofen, Germany) supplemented with $10 \%$ fetal calf serum (Gibco, Paisley, Scotland). A549 Human lung adenocarcinoma cells were incubated in 90\% RPMI supplemented with 10\% fetal bovine serum (Gibco, Paisley, Scotland). All media were supplemented with 100 $\mathrm{IU} / \mathrm{mL}$ penicillin-streptomycin (Gibco, Paisley, Scotland) and cells were incubated at $37{ }^{\circ} \mathrm{C}$ in a humidified atmosphere of $95 \%$ air and $5 \% \mathrm{CO}_{2}$. Exponentially growing cells were plated at $2 \times 10^{4}$ cells/mL into 96 -well microtiter tissue culture plates (Nunc, Denmark) and incubated for $24 \mathrm{~h}$ before the addition of the drugs (the optimum cell number for cytotoxicity assays was determined in preliminary experiments). The stock solutions of the compounds were prepared in dimethyl sulfoxide (DMSO; Sigma Aldrich, Poole, UK) and further dilutions were made with fresh culture medium (the concentration of DMSO in the final culture medium was $<0.1 \%$ which had no effect on the cell viability).

MTT assay

The level of cellular 3-(4,5-dimethylthiazol-2-yl)-2,5-diphenyltetrazolium bromide (MTT) (Sigma) reduction was quantified as previously described in the literature 24,25 
with small modifications. ${ }^{26}$ Compounds 1-8 were investigated for their anticancer activity against A549 human lung adenocarcinoma and C6 rat glioma cell lines. $\mathrm{NIH} / 3 \mathrm{~T} 3$ Mouse embryonic fibroblast cells were used to evaluate the selectivity of the compounds.

After $24 \mathrm{~h}$ of preincubation, compounds 1-8 and cisplatin (positive control) were added to give final concentration in the range $3.9-500 \mu \mathrm{g} / \mathrm{mL}$ and the cells were incubated for $24 \mathrm{~h}$. This concentration range was chosen according to our previous studies. ${ }^{26}$ At the end of this period, MTT was added to a final concentration of 0.5 $\mathrm{mg} / \mathrm{mL}$ and the cells were incubated for $4 \mathrm{~h}$ at $37^{\circ} \mathrm{C}$. After the medium was removed, the formazan crystals formed by MTT metabolism were solubilized by addition of 200 $\mu \mathrm{L}$ DMSO to each well and absorbance was read at $540 \mathrm{~nm}$ with a microtiter plate spectrophotometer (Bio-Tek plate reader, Winooski, VT, USA). Every concentration was repeated in three wells. The half maximal inhibitory concentration $\left(\mathrm{IC}_{50}\right)$ values were defined as the drug concentrations that reduced absorbance to $50 \%$ of control values.

Flow cytometric analyses of apoptosis

After the cells were incubated with compounds $1,2,3,4,5,8$ and cisplatin at $I C_{50}$ concentrations, phosphatidylserine externalization, which indicates early apoptosis, was measured by Annexin V-PI (BD Pharmingen, San Jose, CA, USA) on BD FACSAria flow cytometer for $24 \mathrm{~h}$. Annexin $\mathrm{V}$ staining protocol was applied according to the manufacturer's instructions (BD Pharmingen, San Jose, CA, USA). The cells were then briefly washed with cold phosphate buffer saline (PBS) and suspended in a binding buffer at a concentration of $1 \times 10^{6} \mathrm{cells} / \mathrm{mL}$. Then, $100 \mu \mathrm{L}$ of this solution containing $1 \times 10^{5}$ cells was transferred to a $5 \mathrm{~mL}$ test tube. After $5 \mu \mathrm{L}$ of Annexin-V and PI was added, the cells were incubated for $15 \mathrm{~min}$ at room temperature in the dark. Then $400 \mu \mathrm{L}$ of $1 \mathrm{x}$ binding buffer was added to each tube and the cells were processed for data acquisition, and analyzed on Becton-Dickinson FACSAria flow cytometer using BD FACSDiva software version 6.1.1 (BD Biosciences, San Jose, CA, USA). ${ }^{26}$

Flow cytometric analyses of caspase-3

After C6 cells were incubated with compounds 1, 2, 3, 4, 5, 8 and cisplatin at $I_{50}$ concentrations for $24 \mathrm{~h}$, caspase-3 activity measurement protocol was applied 
according to manufacturer's instructions (BD Pharmingen, San Jose, CA, USA). In brief, the cells were washed with cold phosphate buffer solution (PBS) 1X cells and incubated with $0.5 \mathrm{~mL}$ perm lyse solution for $30 \mathrm{~min}$ at room temperature in the dark. Pellets were washed twice with $0.5 \mathrm{~mL}$ perm wash buffer. Cells were resuspended in $100 \mu \mathrm{L}$ perm wash buffer, and $10 \mu \mathrm{L}$ caspase-3 antibody was added for $20 \mathrm{~min}$ at room temperature in the dark. At least 10,000 cells were counted for each sample and cells were analyzed by BD FACSAria flow cytometry using BD FACSDiva software version 6.1.1 (BD Biosciences, San Jose, CA, USA).

Analysis of mitochondrial membrane potential (JC-1) by flow cytometry

The cells were seeded in six-well plates at a density of $10^{5}$ cells $/ \mathrm{mL}$, and the $\mathrm{IC}_{50}$ dose of compounds $1,2,3,4,5,8$ and cisplatin was added to cells. The cells were incubated in $5 \% \mathrm{CO}_{2}$ air-conditioned atmosphere at $37^{\circ} \mathrm{C}$. After $48 \mathrm{~h}$ of incubation, the cells were trypsinized, washed with PBS, and centrifuged at $400 \times g$ for $5 \mathrm{~min}$. 5,5',6,6'-Tetrachloro-1,1',3,3'-tetraethylbenzimidazolylcarbocyanine iodide (JC-1) dye solution (1× assay buffer $+\mathrm{JC}-1$ stock solution) was added to the cells. The stock solution was prepared by dissolving DMSO. Then the samples were incubated at a temperature of $37^{\circ} \mathrm{C}$ for $10-15 \mathrm{~min}$. After incubation, the cells were washed twice with an assay buffer and analyzed by BD FACSAria flow cytometry using BD FACSDiva software version 6.1.1 (BD Biosciences, San Jose, CA, USA). The cells showing mitochondrial membrane potential disruption were determined as a percentage of all cells. ${ }^{26}$

Cell cycle analysis

After $\mathrm{C} 6$ and $\mathrm{A} 549$ cells were incubated with $\mathrm{IC}_{50}$ concentrations of the compounds for $24 \mathrm{~h}$, cell cycle analyses measurement protocol was applied according to the manufacturer's instructions (BD Biosciences, San Jose, CA, USA). The cells were briefly suspended in the citrate buffer. The cells were then centrifuged at $400 \mathrm{~g}$ for 5 min at room temperature (RT). The supernatant was decanted and $250 \mu \mathrm{L}$ of solution A was added to the pellet and kept at RT for $10 \mathrm{~min}$. Then, $200 \mu \mathrm{L}$ of solution $\mathrm{B}$ was added, gently mixed and kept at RT for $10 \mathrm{~min}$. Then $200 \mu \mathrm{L}$ of solution $\mathrm{C}$ was added. After being gently mixed, it was kept in the dark at $4{ }^{\circ} \mathrm{C}$ for $10 \mathrm{~min}$ and then analyzed on BD FACSAria flow cytometer using BD Bioscience's ModFit software. ${ }^{27}$ 
After 10.000 cells/well were incubated with compounds 1, 2, 3, 4, 5, 8 and cisplatin at $\mathrm{IC}_{50}$ concentrations for $24 \mathrm{~h}$, in cell ELISA colorimetric Akt activity protocol was applied according to the manufacturer's instructions (Thermo Fisher Scientific, Rockford, USA). Briefly, the media was removed and $100 \mu \mathrm{L}$ of $4 \%$ formaldehyde was added to each well. The plate was incubated in a fume hood at room temperature for 15 minutes. Formaldehyde was removed and plate was washed twice with $100 \mu \mathrm{L} /$ well of $1 \mathrm{X}$ TBS. $1 \mathrm{X}$ TBS was removed, $100 \mu \mathrm{L} /$ well of $1 \mathrm{X}$ permeabilization buffer was added and incubated for 15 minutes at room temperature. Permeabilization buffer was removed and plate was washed once with $100 \mu \mathrm{L} /$ well of $1 \mathrm{X}$ TBS. $1 \mathrm{X}$ TBS was removed, $100 \mu \mathrm{L} /$ well quenching solution was added and incubated at room temperature for 20 minutes. Quenching Solution was removed and plate was washed once with $100 \mu \mathrm{L} /$ well of $1 \mathrm{X}$ TBS. Then, $1 \mathrm{X}$ TBS was removed and $100 \mu \mathrm{L} /$ well of blocking buffer was added and incubated at room temperature for 30 minutes. After blocking buffer was removed, $50 \mu \mathrm{L} /$ well of primary antibody was added. A plate sealer was applied and incubated overnight at $4{ }^{\circ} \mathrm{C}$. The primary antibody solution was removed and plate washed three times with 100 $\mu \mathrm{L} /$ well of $1 \mathrm{X}$ wash buffer. After wash buffer was removed, $100 \mu \mathrm{L} /$ well of diluted HRP conjugate was added and incubated for 30 minutes at room temperature. Wash buffer was removed and $100 \mu \mathrm{L} /$ well of TMB substrate was added. Then plate was incubated at room temperature, protected from light. $100 \mu \mathrm{L} /$ well of TMB stop solution was added and the absorbance was measured at $450 \mathrm{~nm}$ within 30 minutes of stopping the reaction. The experiment was performed in triplicate wells. The values of blank wells were subtracted from each well of treated and control cells. Percent Akt activity was defined as the relative absorbance of treated versus untreated control cells.

\section{Statistical analyses}

Statistical Package for the Social Sciences (SPSS) (Chicago, IL) for Windows 15.0 was used for statistical analysis. Data were expressed as mean $\pm S D$. Comparisons were performed by one-way analysis of variance test for normally distributed continuous variables and post hoc analyses of group differences were expressed by the Tukey test. Probability values less than $0.05(p<0.05)$ were accepted as significant.

\section{Molecular docking studies}


Compounds $\mathbf{3}$ and $\mathbf{8}$ were docked to the active site of Akt enzyme. Ligands were set to the physiological $\mathrm{pH}(\mathrm{pH}=7.4)$ at the protonation step and crystal structures of Akt enzyme was retrieved from Protein Data Bank server (PDB code: 3OW4). The structures of compounds $\mathbf{3}$ and $\mathbf{8}$ were submitted in protein preparation module of Schrödinger's Maestro molecular modeling package (Schrödinger Release 2016-2: Schrödinger, LLC, New York, NY, USA). In molecular docking simulations: Glide/XP docking protocols were applied for the prediction of topologies of compounds $\mathbf{3}$ and $\mathbf{8}$ in the active sites of target structures. ${ }^{28}$

\section{RESULTS AND DISCUSSION}

MTT assay was carried out to determine the anticancer effects of the compounds on A549 human lung adenocarcinoma and C6 rat glioma cell lines (Table 2).

Compounds 3 and 4 were more effective on $\mathrm{C} 6$ cell line than cisplatin $\left(\mathrm{IC}_{50}=\right.$ $24.33 \pm 0.58 \mu \mathrm{g} / \mathrm{mL}$ ). Compounds 3 and 4 showed antiproliferative effects on C6 cell line with $\mathrm{IC}_{50}$ values of $22.00 \pm 3.00 \mu \mathrm{g} / \mathrm{mL}$ and $18.50 \pm 4.95 \mu \mathrm{g} / \mathrm{mL}$, respectively. This outcome clearly indicated that $p$-chloro and p-nitro substituents significantly enhanced anticancer activity against C6 cell line. Compounds 1, 2, 5 and 8 exhibited notable cytotoxic activity against $C 6$ cell line with $I_{50}$ values of $50.66 \pm 12.50$, $42.33 \pm 2.52,46.67 \pm 2.89$ and $42.67 \pm 2.08 \mu \mathrm{g} / \mathrm{mL}$, respectively. These results pointed out the importance of the alkyl and aryl groups attached to the acetamido moiety for anticancer activity against $\mathrm{C} 6$ cells.

Compound 3 was found to be the most promising anticancer agent against A549 cell line with an $\mathrm{IC}_{50}$ value of $21.00 \pm 1.15 \mu \mathrm{g} / \mathrm{mL}$ when compared with cisplatin $\left(\mathrm{IC}_{50}=\right.$ $13.50 \pm 2.12 \mu \mathrm{g} / \mathrm{mL})$. Compounds 1,5 and 8 also showed anticancer activity against A549 cell line with $\mathrm{IC}_{50}$ values of $46.33 \pm 2.31,42.67 \pm 2.52$ and $41.33 \pm 1.15 \mu \mathrm{g} / \mathrm{mL}$, respectively. Interestingly, compound 4, the most potent anticancer agent against C6 cell line, did not show any inhibitory activity against A549 cell line $\left(\mathrm{IC}_{50}>500 \mu \mathrm{g} / \mathrm{mL}\right)$. This outcome indicated that $p$-nitro substituent significantly decreased anticancer activity against $A 549$ cell line.

Toxicity to host cells is an important characteristic to assess the safety of drug candidates early in the drug discovery process. In order to evaluate whether the compounds were toxic or non-toxic to healthy cells, the cytotoxic effects of compounds 1-8 on NIH/3T3 mouse embryonic fibroblast cells were investigated using 
MTT assay (Table 2). Generally, the most potent anticancer agents in this series showed low cytotoxicity against $\mathrm{NIH} / 3 \mathrm{~T} 3$ cell line with $\mathrm{IC}_{50}$ values higher than their effective $\mathrm{IC}_{50}$ values.

After $24 \mathrm{~h}$ incubation period, the apoptotic effects of compounds 1, 2, 3, 4, 5 and 8 were analyzed based on Annexin V-PI binding capacities in flow cytometry. Following flow cytometric analyses, early and late apoptotic effects of compounds 1, 2, 3, 4, 5 and 8 (for $\mathrm{IC}_{50}$ doses) on $\mathrm{C} 6$ cell line were determined as $25.7 \%, 23.8 \%, 22.7 \%$, $13.6 \%, 17.4 \%$ and $10.0 \%$, respectively (Table 3 , Fig. 1 ). On the other hand, early and late apoptotic effects of compounds 1, 3, 5 and $\mathbf{8}$ (for $\mathrm{IC}_{50}$ doses) on $\mathrm{A} 549$ cell line were very low $(1.5 \%, 0.3 \%, 0.2 \%$ and $2.3 \%$, respectively). However, their necrotic cell percentages were very high $(60.2 \%, 25.5 \%, 81.1 \%$ and $54.0 \%$, respectively) (Table 4, Fig. 2). According to these findings, compounds $\mathbf{1}, \mathbf{2}$ and $\mathbf{3}$ (25.7, 23.8 and $22.7 \%$ ) showed more apoptotic activity than cisplatin (18.8\%) against C6 cells. On the other hand, compounds 1, 3, 5 and 8 caused necrotic cell death in A549 cells.

Due to the key role of caspase-3 activation in the initiation of cellular events during early apoptotic process ${ }^{29}$, the effects of compounds 1, 2, 3, 4, 5 and 8 on Caspase-3 activation were determined. Caspase-3 positive cell percentages of compounds 1, 3 and cisplatin (for $\mathrm{IC}_{50}$ doses) were determined as 18.6, 49.7 and $14.9 \%$ (Table 5 and Fig. 3). On the other hand, caspase-3 negative cell percentages of these compounds and cisplatin (for $\mathrm{IC}_{50}$ doses) were determined as $80.4,49.5$ and $85.0 \%$ on $\mathrm{C} 6$ cell line. These findings indicated that compound 3 was the most effective compound on Caspase 3 activation in 66 cell line.

In order to investigate the effects of compounds 1, 2, 3, 4, 5 and 8 on mitochondrial membrane potential (MMP) of $\mathrm{C} 6$ cells, the cells were incubated by $\mathrm{IC}_{50}$ concentrations of these compounds for 24 hours. Compounds $\mathbf{3}$ and $\mathbf{8}$ caused higher disturbance on mitochondrial membrane potential than cisplatin in C6 cells. Mitochondrial membrane polarized cell percentages of these compounds and cisplatin (for $\mathrm{IC}_{50}$ doses) were determined as 27.6, 27.9 and 16.9 (Fig. 4 and Table 6), whilst mitochondrial membrane depolarized cell percentages of compounds $\mathbf{3}, \mathbf{8}$ and cisplatin (for IC 50 doses) were determined as 44.7, 28.2 and 24.1, respectively on A549 cell line (Fig. 5 and Table 6).

Due to the importance of cell cycle checkpoints for the progression of cell proliferation ${ }^{30}$, the compounds were analyzed for their effects on cell cycle in A549 
and C6 cells (Table 7). Compounds 2, 3, 4, 5 and $\mathbf{8}$ induced G1/S phase arrest in C6 cells. Among them, compound 3 caused more G1/S phase arrest $(67.21 \%)$ than cisplatin (62.57\%). Compounds 1, 2, 3, 4, 5, 8 arrested G2/M cell cycle in C6 cells. On the other hand, compounds $\mathbf{1 , 5}$ and 8 caused G2/M cell cycle arrest in A549 cells. Only compound 8 caused G1/S cell cycle phase arrest in A549 cells. The effects of compound 8 on G1/S arrest were more significant in A549 cells than C6 cells.

As a consequence of the pivotal role of Akt in regulating diverse cellular functions including cell growth, proliferation, and survival ${ }^{1-6}$, the most potent anticancer agents were investigated for their inhibitory effects on Akt activity (Table 8). Compounds 3 $(92.36 \pm 0.70 \%$ and $91.22 \pm 0.16 \%$ for $\mathrm{C} 6$ and $\mathrm{A} 549$ cells, respectively) and 8 (86.52 $\pm 0.37 \%$ and $70.48 \pm 13.28 \%$ for $\mathrm{C} 6$ and $\mathrm{A} 549$ cells, respectively) were the most potent Akt inhibitors in this series compared to control cells $(p<0.001)$.

Molecular docking simulations were performed to elucidate the possible binding modes of compounds $\mathbf{3}$ and $\mathbf{8}$ in the active site of Akt enzyme (PDB code: 3OW4). The docking results of compounds $\mathbf{3}$ and $\mathbf{8}$ indicated that $\pi-\pi$ interactions, $\mathrm{H}$ bonds and salt bridge formations were responsible for the observed affinity (Fig. 8). The nitrophenyl and chlorophenyl groups and acetamido moiety of compound $\mathbf{3}$ formed $\pi-$ $\pi$ interactions and $\mathrm{H}$-bonds with Ala230, Lys179 and Asp292 residues, respectively. However, the nitrophenylamino group and acetamido moiety of compound 8 presented $\pi-\pi$ interactions, H-bonds and salt bridge formations with Asp439, Glu234, Arg4, Lys158 and 276, Phe442, Ser7 residues, respectively. Nitro substitution on benzothiazole ring was engaged in $\pi-\pi$ interactions with Phe161. Docking scores were found as $-5.55 \mathrm{kcal} / \mathrm{mol}$ for compound 3 and $-5.33 \mathrm{kcal} / \mathrm{mol}$ for compound 8 in the active site of Akt enzyme.

\section{CONCLUSION}

In the current work, in vitro and in silico studies were carried out to determine the mechanism of antitumor action of thiadiazole-based anticancer agents. Compounds 3 and 8 induced apoptosis and cell cycle arrest in G1/S and G2/M phases in C6 cell line through the inhibition of Akt activity. Docking studies also confirmed that compounds $\mathbf{3}$ and $\mathbf{8}$ demonstrated high affinity to the active site of Akt enzyme by forming $\pi-\pi$ interactions, hydrogen bonds and salt-bridge formation with proper 
residues. According to in vitro and docking studies, compounds $\mathbf{3}$ and $\mathbf{8}$ stand out as promising antiglioma agents for further in vitro and in vivo studies.

\section{ACKNOWLEDGEMENT}

We thank Anadolu University Medicinal Plants, Drugs and Scientific Research Center (AUBIBAM) for the equipments used in cytotoxicity assays.

Conflict of Interest: No conflict of interest was declared by the authors.

\section{REFERENCES}

1. Nitulescu GM, Margina D, Juzenas P, Peng Q, Olaru OT, Saloustros E, Fenga C, Spandidos DA, Libra M, Tsatsakis AM. Akt inhibitors in cancer treatment: The long journey from drug discovery to clinical use (Review). Int J Oncol. 2016;48(3):869_ 885.

2. McDowell KA, Riggins GJ, Gallia GL. Targeting the AKT Pathway in Glioblastoma. Curr Pharm Des. 2011;17:2411-2420.

3. Morrow JK, Du-Cuny L, Chen L, Meuillet EJ, Mash EA, Powis G, Zhang S. Recent Development of Anticancer Therapeutics Targeting Akt. Recent Pat Anti-Cancer Drug Discov. 2011;6:146-159.

4. Cassinelli G, Zuco V, Gatti L, Lanzi C, Zaffaroni N, Colombo D, Perego P. Targeting the Akt Kinase to Modulate Survival, Invasiveness and Drug Resistance of Cancer Cells. Curr Med Chem. 2013;20:1923-1945.

5. Brown JS, Banerji U. Maximising the potential of AKT inhibitors as anti-cancer treatments. Pharmacol Ther. 2017;172:101-115.

6. Roy NK, Bordoloi D, Monisha J, Padmavathi G, Kotoky J, Golla R, Kunnumakkara AB. Specific Targeting of Akt Kinase Isoforms: Taking the Precise Path for Prevention and Treatment of Cancer. Curr Drug Targets 2017;18:421-435.

7. Jain AK, Sharma S, Vaidya A, Ravichandran V, Agrawal RK. 1,3,4-Thiadiazole and Its Derivatives: A Review on Recent Progress in Biological Activities. Chem Biol Drug Des. 2013;81:557-576.

8. Li Y, Geng J, Liu Y, Yu S, Zhao G. Thiadiazole-A Promising Structure in Medicinal Chemistry. ChemMedChem. 2013;8:27-41. 
9. Hu Y, Li CY, Wang XM, Yang YH, Zhu HL. 1,3,4-Thiadiazole: Synthesis, Reactions, and Applications in Medicinal, Agricultural, and Materials Chemistry. Chem Rev. 2014;114:5572-5610.

10. Matysiak J. Biological and Pharmacological Activities of 1,3,4-Thiadiazole Based Compounds. Mini-Rev Med Chem. 2015;15:762-775.

11. Haider S, Alam MS, Hamid H. 1,3,4-Thiadiazoles: A Potent Multi Targeted Pharmacological Scaffold. Eur J Med Chem. 2015;92:156-177.

12. Aliabadi A. 1,3,4-Thiadiazole Based Anticancer Agents. Anti-Cancer Agents Med Chem. 2016;16:1301-1314.

13. Dawood KM, Farghaly TA. Thiadiazole Inhibitors: A Patent Review. Expert Opin Ther Pat. 2017;27:477-505.

14. Raj V, Rai A, Saha S. Human Cancer Cell Line Based Approach of 1,3,4thiadiazole and its Fused Ring: A Comprehensive Review. Anti-Cancer Agents Med Chem. 2017;17:500-523.

15. Chou JY, Lai SY, Pan SL, Jow GM, Chern JW, Guh JH. Investigation of anticancer mechanism of thiadiazole-based compound in human non-small cell lung cancer A549 cells. Biochem Pharmacol. 2003;66(1):115-124.

16. Radi M, Crespan E, Botta G, Falchi F, Maga G, Manetti F, Corradi V, Mancini M, Santucci MA, Schenone S, Botta M. Discovery and SAR of 1,3,4-Thiadiazole Derivatives as Potent Abl Tyrosine Kinase Inhibitors and Cytodifferentiating Agents. Bioorg Med Chem Lett. 2008;18:1207-1211.

17. Sun J, Yang YS, Li W, Zhang YB, Wang XL, Tang JF, Zhu HL. Synthesis, Biological Evaluation and Molecular Docking Studies of 1,3,4-Thiadiazole Derivatives Containing 1,4-Benzodioxan as Potential Antitumor Agents. Bioorg Med Chem Lett. 2011;21:6116-6121.

18. Juszczak M, Matysiak J, Szeliga M, Pożarowski $P$, Niewiadomy A, Albrecht J, Rzeski W. 2-Amino-1,3,4-thiadiazole Derivative (FABT) Inhibits the Extracellular Signal-Regulated Kinase Pathway and Induces Cell Cycle Arrest in Human NonSmall Lung Carcinoma Cells. Bioorg Med Chem Lett. 2012;22:5466-5469. 
19. Guan P, Sun F, Hou X, Wang F, Yi F, Xu W, Fang H. Design, Synthesis and Preliminary Bioactivity Studies of 1,3,4-Thiadiazole Hydroxamic Acid Derivatives as Novel Histone Deacetylase Inhibitors. Bioorg Med Chem. 2012;20:3865-3872.

20. Li YJ, Qin YJ, Makawana JA, Wang YT, Zhang YQ, Zhang YL, Yang MR, Jiang AQ, Zhu HL. Synthesis, Biological Evaluation and Molecular Modeling of 1,3,4Thiadiazol-2-amide Derivatives as Novel Antitubulin Agents. Bioorg Med Chem. 2014;22:4312-4322.

21. Hosseinzadeh L, Khorand A, Aliabadi A. Discovery of 2-Phenyl-N-(5(trifluoromethyl)-1,3,4-thiadiazol-2-yl)acetamide Derivatives as Apoptosis Inducers via the Caspase Pathway with Potential Anticancer Activity. Arch Pharm Chem Life Sci. 2013;346:812-818.

22. Guan $\mathrm{P}$, Wang $L$, Hou $X$, Wan $Y, X u$ W, Tang $W$, Fang $H$. Improved Antiproliferative Activity of 1,3,4-Thiadiazole-Containing Histone Deacetylase (HDAC) Inhibitors by Introduction of the Heteroaromatic Surface Recognition Motif. Bioorg Med Chem. 2014;22:5766-5775.

23. Altıntop MD, Can ÖD, Demir Özkay Ü, Kaplancıklı ZA. Synthesis and Evaluation of New 1,3,4-Thiadiazole Derivatives as Antinociceptive Agents. Molecules 2016;21(8),1004.

24. Mossmann T. Rapid colorimetric assay for cellular growth and survival: application to proliferation and cytotoxicity assays. J Immunol Methods 1983;65:5563.

25. Keiser K, Johnson CC, Tipton DA. Cytotoxicity of mineral trioxide aggregate using human periodontal ligament fibroblasts. J Endod. 2000;26:288-291.

26. Altıntop MD, Temel HE, Sever B, Akalın Çiftçi G, Kaplancıklı ZA. Synthesis and Evaluation of New Benzodioxole-Based Thiosemicarbazone Derivatives as Potential Antitumor Agents. Molecules 2016;21(11),1598.

27. Çiftçi GA, Işcan A, Kutlu M. Escin reduces cell proliferation and induces apoptosis on glioma and lung adenocarcinoma cell lines. Cytotechnology 2015;67(5):893-904.

28. Bencsik JR, Xiao D, Blake JF, Kallan NC, Mitchell IS, Spencer KL, Xu R, Gloor SL, Martinson M, Risom T, Woessner RD, Dizon F, Wu WI, Vigers GP, Brandhuber BJ, Skelton NJ, Prior WW, Murray LJ. Discovery of dihydrothieno- and 
dihydrofuropyrimidines as potent pan Akt inhibitors. Bioorg Med Chem Lett. 2010;20:7037-7041.

29. Porter AG, Jänicke RU. Emerging roles of caspase-3 in apoptosis. Cell Death Differ. 1999;6:99-104.

30. Williams GH, Stoeber K. The cell cycle and cancer. J Pathol. 2012;226:352-364. 
Table 1. The chemical structures of compounds 1-8

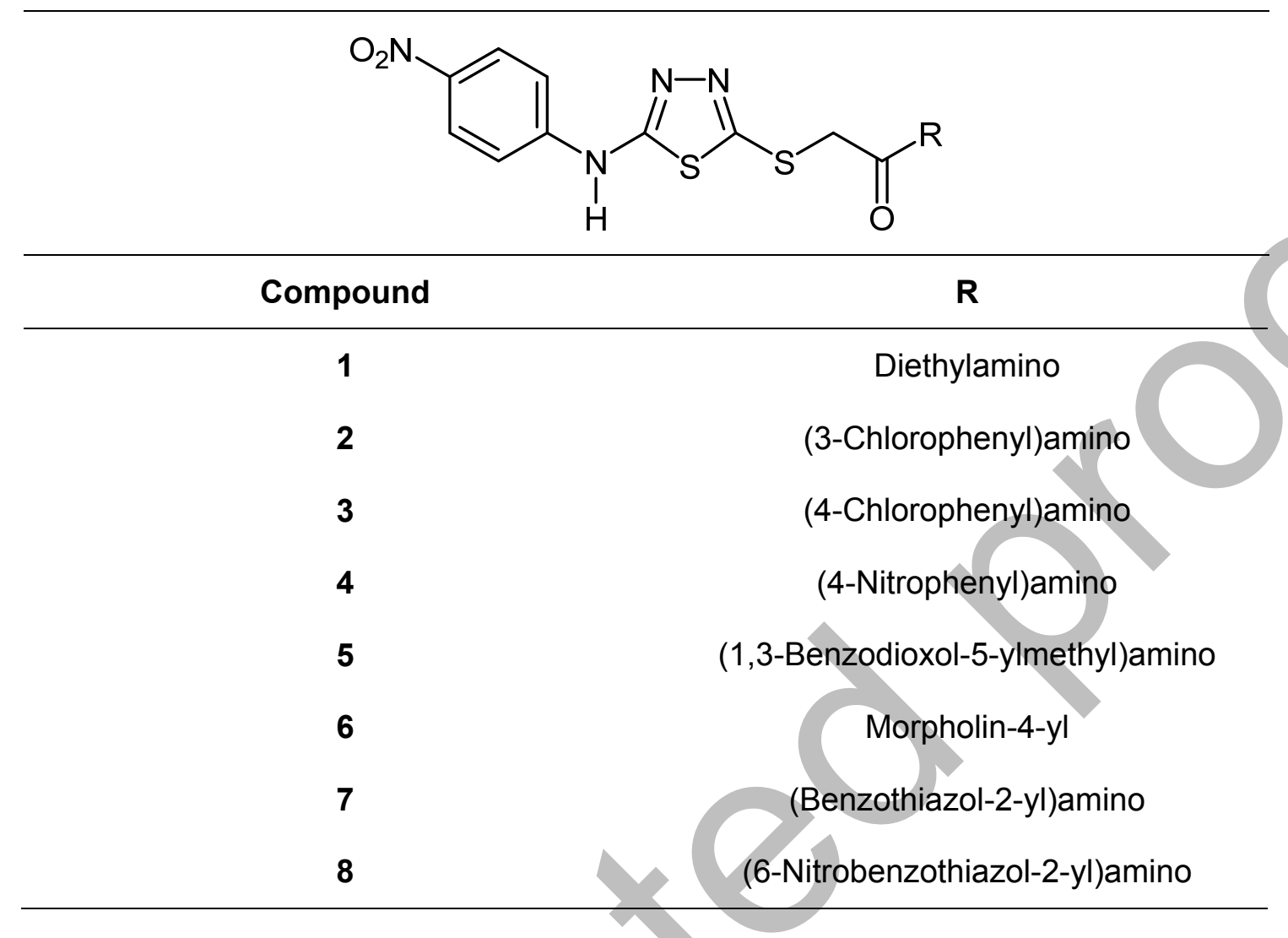


Table 2. IC $\mathrm{C}_{50}$ values of the compounds against A549, C6 and NIH/3T3 cells for $24 \mathrm{~h}$

\begin{tabular}{cccc}
\hline Compound & C6 cell line & A549 cell line & NIH/3T3 cell line \\
\hline $\mathbf{1}$ & $50.66 \pm 12.50$ & $46.33 \pm 2.31$ & $>500$ \\
$\mathbf{2}$ & $42.33 \pm 2.52$ & $160.00 \pm 34.64$ & $175.00 \pm 35.35$ \\
$\mathbf{3}$ & $22.00 \pm 3.00$ & $21.00 \pm 1.15$ & $91.67 \pm 7.64$ \\
$\mathbf{4}$ & $18.50 \pm 4.95$ & $>500$ & $275.00 \pm 35.36$ \\
$\mathbf{5}$ & $46.67 \pm 2.89$ & $42.67 \pm 2.52$ & $450.00 \pm 70.71$ \\
$\mathbf{6}$ & $135.00 \pm 21.21$ & $91.67 \pm 2.89$ & $>500$ \\
$\mathbf{7}$ & $76.67 \pm 2.89$ & $88.33 \pm 7.64$ & $480.00 \pm 26.46$ \\
$\mathbf{8}$ & $42.67 \pm 2.08$ & $41.33 \pm 1.15$ & $125.00 \pm 35.36$ \\
Cisplatin & $24.33 \pm 0.58$ & $13.50 \pm 2.12$ & $\mathrm{nt}$ \\
\hline
\end{tabular}

nt: not tested.

Values are given as mean $\pm S D$. 
Table 3. Percents of typical quadrant analysis of Annexin V FITC/Propidium lodide flow cytometry of C6 cells treated with compounds 1, 2, 3, 4, 5, 8 and cisplatin

\begin{tabular}{ccccc}
\hline Groups & $\begin{array}{c}\text { Early } \\
\text { apoptotic } \\
\text { cells\% }\end{array}$ & $\begin{array}{c}\text { Late } \\
\text { apoptotic } \\
\text { cells\% }\end{array}$ & $\begin{array}{c}\text { Viable } \\
\text { cells\% }\end{array}$ & $\begin{array}{c}\text { Necrotic } \\
\text { cells\% }\end{array}$ \\
\hline Control (untreated) & 5.2 & 4.3 & 87.0 & 3.1 \\
Compound $\mathbf{1}$ treated cells & 9.7 & 16.0 & 66.1 & 8.2 \\
Compound $\mathbf{2}$ treated cells & 12.2 & 11.6 & 63.5 & 12.8 \\
Compound $\mathbf{3}$ treated cells & 12.8 & 9.9 & 21.8 & 21.8 \\
Compound $\mathbf{4}$ treated cells & 9.6 & 4.0 & 78.7 & 7.6 \\
Compound $\mathbf{5}$ treated cells & 11.1 & 6.3 & 74.6 & 8.0 \\
Compound $\mathbf{8}$ treated cells & 4.7 & 5.3 & 71.7 & 18.3 \\
Cisplatin treated cells & 3.4 & 15.4 & 55.5 & 25.7 \\
\hline
\end{tabular}

C6 cells were cultured for 24 hours in medium with compounds 1, 2, 3, 4, 5, 8 and cisplatin at $I_{50}$ values. At least 10,000 cells were analyzed per sample, and quadrant analysis was performed. 
Table 4. Percents of typical quadrant analysis of Annexin V FITC/Propidium lodide flow cytometry of A549 cells treated with compounds 1, 3, 5, 8 and cisplatin

\begin{tabular}{ccccc}
\hline Groups & $\begin{array}{c}\text { Early } \\
\text { apoptotic } \\
\text { cells\% }\end{array}$ & $\begin{array}{c}\text { Late } \\
\text { apoptotic } \\
\text { cells\% }\end{array}$ & $\begin{array}{c}\text { Viable } \\
\text { cells\% }\end{array}$ & $\begin{array}{c}\text { Necrotic } \\
\text { cells\% }\end{array}$ \\
\hline Control (untreated) & 3.6 & 2.5 & 91.7 & 2.2 \\
Compound $\mathbf{1}$ treated cells & 0.3 & 1.2 & 38.2 & 60.2 \\
Compound $\mathbf{3}$ treated cells & 0.1 & 0.2 & 74.2 & 25.5 \\
Compound $\mathbf{5}$ treated cells & 0.0 & 0.2 & 18.7 & 81.1 \\
Compound 8 treated cells & 0.7 & 1.6 & 43.6 & 54.0 \\
Cisplatin treated cells & 0.0 & 0.8 & 30.5 & 68.7 \\
\hline
\end{tabular}

A549 cells were cultured for 24 hours in medium with compounds 1, 3, 5, 8 and cisplatin at $I_{50}$ values. At least 10,000 cells were analyzed per sample, and quadrant analysis was performed. 
Table 5. Percents of quadrant analysis of active caspase-3 phycoerythrin staining by flow cytometry of $\mathrm{C} 6$ cells treated with $\mathrm{IC}_{50}$ concentrations of compounds $1,2,3,4,5,8$ and cisplatin

\begin{tabular}{ccc}
\hline Groups & Caspase-3 (-) cells \% & Caspase-3 (+) cells \% \\
\hline Control (untreated) & 96.3 & 3.1 \\
Compound $\mathbf{1}$ treated cells & 80.4 & 18.6 \\
Compound $\mathbf{2}$ treated cells & 88.6 & 11.1 \\
Compound $\mathbf{3}$ treated cells & 49.5 & 49.7 \\
Compound $\mathbf{4}$ treated cells & 87.7 & 12.7 \\
Compound $\mathbf{5}$ treated cells & 89.4 & 10.1 \\
Compound $\mathbf{8}$ treated cells & 97.4 & 2.0 \\
Cisplatin treated cells & 85.0 & 14.9 \\
\hline
\end{tabular}

C6 cells were cultured for 24 hours in medium with compounds 1, 2, 3, 4, 5, 8 and cisplatin at $1 C_{50}$ concentrations). At least 10,000 cells were analyzed per sample, and quadrant analysis was performed. 
Table 6. Reduction of the mitochondrial membrane potential in $\mathrm{C} 6$ and $\mathrm{A} 549$ cells by $\mathrm{IC}_{50}$ concentrations of the compounds and cisplatin

\begin{tabular}{|c|c|c|c|c|}
\hline \multirow{2}{*}{ Groups } & \multicolumn{2}{|c|}{$\begin{array}{l}\text { Mitochondrial membrane } \\
\text { polarized (P1) cells (\%) }\end{array}$} & \multicolumn{2}{|c|}{$\begin{array}{l}\text { Mitochondrial membrane } \\
\text { depolarized cells (P2) (\%) }\end{array}$} \\
\hline & C6 cells & A549 cells & C6 cells & A549 cells \\
\hline Control (untreated) & 96.0 & 92.5 & 1.3 & 3.3 \\
\hline Compound 1 treated cells & 61.7 & 9.0 & 45.4 & \\
\hline Compound 2 treated cells & 87.2 & ------ & 10.8 & \\
\hline Compound $\mathbf{3}$ treated cells & 58.1 & 19.9 & 27.6 & 44.7 \\
\hline Compound $\mathbf{4}$ treated cells & 78.5 & ------- & 1 & \\
\hline Compound $\mathbf{5}$ treated cells & 75.5 & 37.1 & & 12.9 \\
\hline Compound 8 treated cells & 63.0 & 44.8 & 27.9 & 28.2 \\
\hline Cisplatin treated cells & 77.0 & 38.8 & 16.9 & 24.1 \\
\hline
\end{tabular}

Cells treated or untreated with $I_{50}$ concentrations of the compounds and cisplatin for $24 \mathrm{~h}$ were stained with mitochondrial-selectivite $\mathrm{JC}-1$ dye and analyzed by flow cytometry. P1: mitochondrial membrane polarized cells, P2: mitochondrial membrane depolarized cells. 
Table 7. C6 and A549 cell percentages on G1/S and G2/M cell cycle phases

\begin{tabular}{ccccc}
\hline \multirow{2}{*}{ Compounds } & \multicolumn{2}{c}{ A549 cell line } & \multicolumn{2}{c}{ C6 cell line } \\
\cline { 2 - 5 } & G1/S Phase & G2/M Phase & G1/S Phase & G2/M Phase \\
\hline Control & 62.9 & 2.85 & 49.99 & 7.69 \\
Compound 1 treated cells & 58.05 & 5.51 & 49.26 & 10.91 \\
Compound 2 treated cells & --- & --- & 51.13 & 8.42 \\
Compound 3 treated cells & --- & --- & 67.21 & 8.59 \\
Compound 4 treated cells & --- & --- & 56.99 & 11.48 \\
Compound 5 treated cells & 61.84 & 4.64 & 57.71 & 7.96 \\
Compound 8 treated cells & 73.86 & 11.87 & 57.53 & 10.35 \\
Cisplatin & 68.22 & 6.27 & 62.57 & 11.21 \\
\hline
\end{tabular}


Table 8. Akt inhibitory effects of compounds 1, 2, 3, 4, 5, 8 and cisplatin

\begin{tabular}{ccc}
\hline \multirow{2}{*}{ Compound } & \multicolumn{2}{c}{ Inhibition\% } \\
\cline { 2 - 3 } & C6 cell line & A549 cell line \\
\hline $\mathbf{2}$ & $38.68 \pm 0.75^{*}$ & $43.39 \pm 5.86^{*}$ \\
$\mathbf{3}$ & $66.37 \pm 2.47^{* *}$ & --- \\
$\mathbf{4}$ & $92.36 \pm 0.70^{* * *}$ & $91.22 \pm 0.16^{* * *}$ \\
$\mathbf{5}$ & $43.30 \pm 32.03^{*}$ & -- \\
$\mathbf{8}$ & $68.84 \pm 20.82^{* *}$ & $66.57 \pm 8.75^{* *}$ \\
Cisplatin & $86.52 \pm 0.37^{* * *}$ & $70.48 \pm 13.28^{* * *}$ \\
\end{tabular}

Significant differences versus control values, ${ }^{*} p<0.05,{ }^{* *} p<0.01,{ }^{* * *} p<0.001$. Values are given as mean $\pm S D$. 